\title{
Использование ионообменной хроматографии для получения гомогенного препарата глутаматдегидрогеназы из проростков пшеницы
}

\author{
(c) 2021 Анохина Г.Б., Дедов Я.И., Епринцев А.Т. \\ Воронежский государственный университет, Воронеж
}

Поступила в редакцию 10.02.2021 г.

DOI: $10.17308 /$ sorpchrom.2021.21/3473

Благодаря пятистадийной очистке был получен гомогенный препарат глутаматдегидрогеназы (ГДГ, L-глутамат: НАД(Ф)Н-оксидоредуктаза 1.4.1.3), очищенный в 319.5 раз с удельной активностью 377 Е/мг белка и выходом 3.7\%. Обычно очистка энзимов в нашей лаборатории осуществляется по следующей общей схеме: гомогенизация растительного материала (получение экстракта энзима), фракционирование белков-ферментов сульфатом аммония, гель-фильтрация на сефадексе G-25, обеспечивающая обессоливание белков, ионообменная хроматография на ДЭАЭ-Sephacel, десорбция ферментативной активности осуществлялась градиентом концентрации $\mathrm{NaCl}(0.15-0.3 \mathrm{M})$. Последнюю стадию очистки осуществляли путем гель-хроматографии на сефадексе G-200. Известно, что ингибирующее действие на глутаматдегидрогеназу оказывают АТФ и метаболические интермедиаты (глутамат и 2оксоглутарат). Активация ферментативной активности наблюдается при воздействии АМФ, ионов кальция и магния, а также сульфата аммония. Наибольший эффект из перечня всех хроматографических методов (ионообменная, распределительная, гель-фильтрация и др.) имело использование ДЭАЭSephacel. При этом степень очистки ГДГ составляла более чем в 300 раз.

Проведенный ПААГ-электрофорез с последующим специфическим проявлением тетразолиевым методом позволил обнаружить у очищенного белка глутаматдегидрогеназную активность. $\mathrm{pH}$ оптимум полученной ГДГ по реакции восстановительного аминирования составляет 8.5 , также как и по реакции окислительного дезаминирования. Были получены кинетические характеристики сродства глутаматдегидрогеназы к субстратам различной природы. Величины константы Михаэлиса для 2-оксоглутарата составляли 2.75 , а для глутамата -14.9 , что может говорить о преобладании $\beta$-субъединиц в структуре олигомера ГДГ. Анализ этих данных свидетельствует о значительно большем сродстве исследуемого энзима к 2-оксоглутарату.

Ключевые слова: глутаматдегидрогеназа, пшеница, очистка, константа Михаэлиса, оптимум $\mathrm{pH}$, Triticum aestivum.

\section{Введение}

Глутаматдегидрогеназа (ГДГ, L-глутамат: НАД(Ф)Н-оксидоредуктаза 1.4.1.3) фермент, участвующий в обмене азотсодержащих интермедиатов, обеспечивает функционирование обходного пути цикла трикарбоновых кислот - ГАМКшунта. Энзим катализирует реакцию восстановительного аминирования 2-оксоглутарата до глутамата, а также обратную реакцию окислительного дезаминирования глутамата [1].

У высших растений фермент присутствует во всех тканях и органах без исключения. По своей структуре ГДГ чаще всего представляет собой гомополимер с различным количеством субъединиц (от 2 до 6), имеющий молекулярную массу от 40 до 60кДа [2]. Гексамерная форма является самой распространенной и наиболее изученной. 
Свойства глутаматдегидрогеназы различных организмов изучаются давно. В качестве ингибиторов ГДГ чаще всего выступают двухвалентные ионы металлов, различные аминокислоты и нуклеозидфосфаты $[3,4]$. Они же могут выступать в качестве активаторов, наряду с некоторыми аминокислотами, такими как аспартат, лейцин и аспарагин $[5,6]$. В зависимости от организма, величина константы Михаэлиса по отношению к глутамату обычно не превышает 4.6 мМ. Однако, имеются исключения. Так, ГДГ, выделенная из сои, имела $\mathrm{Km}$ по глутамату равную 7.2 мМ при рН 8.0 и 15.8 мМ при pH $9.3[7,8]$.

При этом, значение Км по 2-оксоглутарату составляло $3.2 \mathrm{MM}(\mathrm{pH} 8.0)$ и 12.3 мМ (рH 9.3). Известно, что в разных организмах наблюдается широкий спектр значений константы Михаэлиса по отношению к аммонию, которые могут варьировать от 6.5 до 60 мМ [9]. ГДГ, полученная из сои, имела величину Км по аммонию 35.5 мМ при рН 8.0 и 20.1 мМ при рН $9.3[8]$.

Глутаматдегидрогеназа отличается термостабильностью. В зависимости от организма, температурный оптимум работы фермента лежит в области $20-45^{\circ} \mathrm{C}$. Из литературных источников известно, что у термофильных бактерий температурный оптимум глутаматдегидрогеназы может достигать $90^{\circ} \mathrm{C}[10]$.

Для прямой и обратной реакции значения оптимума $\mathrm{pH}$ чаще всего имеют разные значения. Как правило, значение оптимума рН для прямой реакции ниже, чем для обратной. У высших растений оптимум лежит в районе $\mathrm{pH}$ 7-9 [11-13]. Так, ГДГ, полученная из сои, имеет оптимум работы фермента по реакции аминирования при $\mathrm{pH} 8.0$, а по реакции дезаминирования при значении 9.3 [8]. Стоит отметить, что свойства ГДГ напрямую зависят от субъединичного состава. Известно, что $\alpha$-субъединица обеспечивает протекание реакции в сторону синтеза 2-оксоглутарата, а $\beta$-субъединица - в сторону образования глутамата $[8,14]$.
В связи с этим, целью данной работы являлась разработка пятистадийных этапов получения гомогенного препарата ГДГ из проростков пшеницы и исследование кинетических характеристик фермента в реакциях аминирования и дезаминирования

\section{Экспериментальная часть}

В качестве объекта исследования использовали проростки пшеницы, выращенные гидропонным способом при 10часовом световом дне с интенсивностью света $25 \mathrm{Bт} / \mathrm{M}^{2}$. Температура выращивания составляла $25^{\circ} \mathrm{C}$.

Активность ГДГ по реакции аминирования определяли по изменению оптической плотности раствора, содержащего 2.5 мМ 2-оксоглутарата, 0.25 мМ НАДН, 50 мМ хлорида аммония, 100 мМ HEPES буфер $\mathrm{pH} 8.0$ [15]. Реакцию инициировали добавлением фермента.

Активность ГДГ по реакции дезаминирования определяли путём измерения оптической плотности раствора, содержащего 100 мМ HEPES буфер $\mathrm{pH} 8.5$, 3 мМ НАД, 1.0 мМ хлорид кальция, 50 мМ глутамат натрия [16]. Реакцию инициировали добавлением фермента.

Очистку ГДГ проводили по модифицированной методике в пять стадий при постоянной температуре $4^{\circ} \mathrm{C}[17,18]$. Листья пшеницы гомогенизировали в среде выделения. Фракционирование сульфатом аммония проводили в две стадии: от 0 до 35\% насыщения раствора и от 35 до $70 \%$. Полученный осадок ресуспендировали в 50 мМ Трис-HCl буфере, $\mathrm{pH} 7.8$, в объеме $2 \mathrm{~cm}^{3}$. Соли аммония удаляли гель-фильтрацией через колонку с сефадексом G-25. Элюцию белков проводили 50 мМ Трис-HCl буфером, $\mathrm{pH}$ 8.0. Ионообменную хроматографию осуществляли на колонке с ДЭАЭ-Sephacel (SigmaAldrich, США). Десорбцию белка производили линейным градиентом концентрации $\mathrm{NaCl}$ от 0.15 до $0.3 \mathrm{M}$ [10]. Десорбция фермента происходила при концентрации $\mathrm{NaCl} 254$ мМ. В дальнейшем, очистку 
препарата проводили путем гель-фильтрации на сефадексе G-200.

Электрофоретические исследования белков проводили в 7.5\% полиакриламидном геле [19]. Универсальное окрашивание белков в гелях осуществляли с помощью $\mathrm{AgNO}_{3}$ [20]. Специфическое проявление ГДГ осуществляли с помощью тетразолиевого метода [21]. Белок определяли по методу Лоури [22].

Влияние значений $\mathrm{pH}$ на скорость ферментативной реакции полученных молекулярных форм ГДГ определяли путем проведения серии измерений скорости ферментативной реакции при различных значениях $\mathrm{pH}$. Константы Михаэлиса полученных ферментных препаратов определяли с использованием в качестве субстрата 2-оксоглутарата (прямая реакция), а также глутамата (обратная реакция). $\mathrm{K}_{\mathrm{m}}$ определяли по графику Лайнуивера-Бэрка методом двойных обратных координат.

Опыты проводили в 3-4-кратной повторности, аналитические определения для каждой пробы осуществляли в трех повторностях. Предварительная оценка характера распределения проводилась по асимметрии и эксцессу (Excel, Microsoft
Office), а также с помощью критерия Колмогорова-Смирнова. Полученные значения позволили оценить характер распределения как нормальный. Критерий Стьюдента использовался с применением поправки на множественные сравнения (поправка Бонферрони) [23]. Дополнительно применялся однофакторный дисперсионный анализ ANOVA (влияние фактора достоверно при $\mathrm{p}<0.05)$.

\section{Обсуждение результатов}

В результате модифицированной на нашей кафедре схемы пятистадийной очистки из зеленых проростков пшеницы был выделен и очищен электрофоретически гомогенный препарат ГДГ (в табл. 1). Наиболее значимая стадия ионообменная хроматография на ДЭАЭSephacel, которая позволила очистить препарат ГДГ более чем в 300 раз. Получение глутаматдегидрогеназного препарата в гомогенном состоянии позволило изучить важные каталитические и кинетические характеристики ферментативной реакции.

Таблица 1. Стадии очистки глутаматдегидрогеназы из проростков пшеницы Table 1. Stages of purification of glutamate dehydrogenase from wheat seedlings

\begin{tabular}{|c|c|c|c|c|c|c|}
\hline Стадия & $\begin{array}{c}\text { Объем, } \\
\text { мл }\end{array}$ & $\begin{array}{c}\text { Белок, } \\
\text { мг }\end{array}$ & $\begin{array}{c}\text { Общая ак- } \\
\text { тивность, Е }\end{array}$ & $\begin{array}{c}\text { Удельная } \\
\text { актив- } \\
\text { ность, Е/мг } \\
\text { белка }\end{array}$ & $\begin{array}{c}\text { Вы- } \\
\text { ход, \% }\end{array}$ & $\begin{array}{c}\text { Степень } \\
\text { очистки }\end{array}$ \\
\hline Гомогенат & 10 & 148 & 175.2 & 1.18 & 100.0 & 1.0 \\
\hline $\begin{array}{c}\text { Фракционирова- } \\
\text { ние сульфатом ам- } \\
\text { мония, 70\% насы- } \\
\text { щения }\end{array}$ & 7.5 & 31.3 & 90.3 & 2.88 & 51.5 & 2.4 \\
\hline $\begin{array}{c}\text { Гель-фильтрация } \\
\text { через сефадекс } \\
\text { G-25 }\end{array}$ & 4.0 & 1.21 & 19.5 & 16.1 & 11.1 & 13.64 \\
\hline $\begin{array}{c}\text { дЭАЭ- Sерһасеl } \\
\text { Гель-фильтрация } \\
\text { через сефадекс } \\
\text { G-200 }\end{array}$ & 2.0 & 0.1 & 16.3 & 163 & 9.3 & 138.1 \\
\hline
\end{tabular}




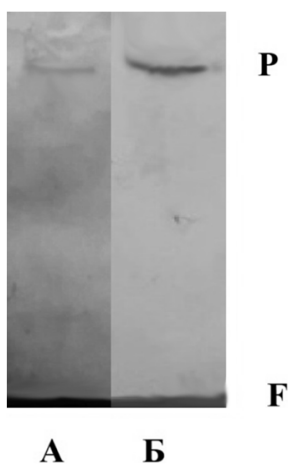

Рис. 1. Электрофореграмма очищенного препарата ГДГ: А - с использованием нитрата серебра; Б - специфическое проявление ГДГ; Р - белковая полоса, $\mathrm{F}$ - фронт красителя

Fig. 1. Electropherogram of the purified GDH preparation: A - using silver nitrate; B - specific manifestation of GDH, $\mathrm{P}$ - protein band, $\mathrm{F}$ - dye front

Фракционирование сульфатом аммония (до 70\% насыщения) и гель-фильтрация на сефадексе G-25 позволили получить фермент с удельной активностью $16.1 \mathrm{E/мг} \mathrm{белка.} \mathrm{Проведение} \mathrm{ионообмен-}$ ной хроматографии на колонке с ДЭАЭSephacel позволило обнаружить пик активности ГДГ, который десорбировали хлористым натрием (254 мМ). Полученный ферментный препарат с удельной активностью 163 Е/мг белка в дальнейшем подвергался гель-хроматографии на сефадексе G-200 (табл. 1).

B результате проведенных операций ГДГ была очищена до удельной активности 377 Е/мг белка, при этом степень очистки составила 319.5 раз и выход $3.7 \%$.

Проведение электрофореза в ПААГ с универсальным окрашиванием белков нитратом серебра позволило установить, что ГДГ была получена в гомогенном состоянии (рис. 1А). При помощи модифицированного тетразолиевого метода окрашивания была определена принадлежность полученного очищенного белка к глутаматдегидрогеназе (рис. 1Б). Значение $\mathrm{R}_{\mathrm{f}}$ для полученного ферментного препарата составляло 0.12 [11]. Следует отметить, что относительная электрофоретическая подвижность глутаматдегидрогеназы из разных объектов является консервативной величиной. Так, значение $\mathrm{R}_{\mathrm{f}}$ для ГДГ из 12-дневных проростков кукурузы равняется 0.13. По мнению некоторых авторов величина этого показателя обусловлена количеством субъединиц и их соотношением $[8,14]$.

Для очищенного препарата глутаматдегидрогеназы был измерен оптимум $\mathrm{pH}$, который составил 8.5 и для прямой, и для обратной реакции (рис. 2-3, табл. 2). Ранее было показано, что величина $\mathrm{pH}$ оптимума для ГДГ (реакция аминирования) из листьев кукурузы составляет 8.5, а из листьев сои 8.0. В случае осуществления реакции дезаминирования $\mathrm{pH}-о п-$ тимум составлял для ГДГ из кукурузы 9.0 $[8,24]$.

Полученный ферментный препарат глутаматдегидрогеназы из проростков пшеницы имел различные значения К для 2-оксоглутарата ( $\kappa_{\mathrm{M}}=2.75$ (рис. $\left.\left.4 \mathrm{~A}\right)\right)$, а для глутамата - 14.9 (рис. 4Б, табл. 2). Для ГДГ из листьев кукурузы было обнаружено более высокое сродство к 2-оксоглутарату, что может быть связано со структурой молекулы белка, а также с особенностями метаболизма $\mathrm{C}_{3}$ и $\mathrm{C}_{4}$ растений [24]. Известно, что $\alpha$-субъединицы обеспечивают каталитическое действие фермента в реакции дезаминирования, а $\beta$-субъединицы - по направлению аминирования кетокислоты. Полученный ферментный препарат содержит доминирующее количество $\beta$-субъединиц. Точный количественный анализ субъединичного строения глутаматдегидрогеназы можно изучить в помощью масс-спектрометрических методов или блоттинга, что в данный момент затруднительно. 


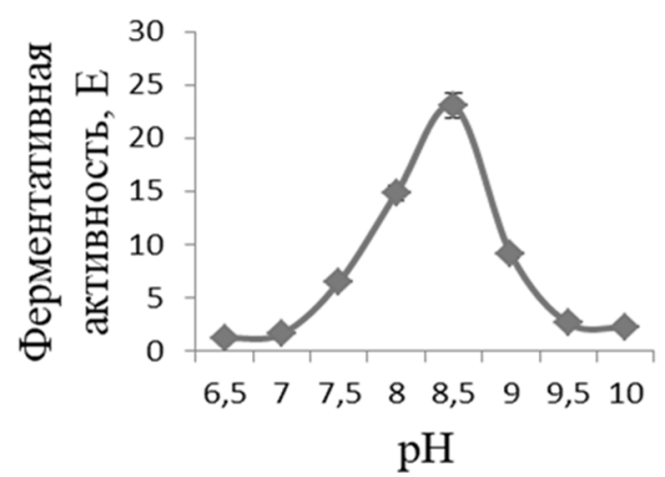

Рис. 2. Зависимость активности полученного препарата глутаматдегидрогеназы от значения $\mathrm{pH}$ для реакции восстановительного аминирования 2-оксоглутарата

Fig. 2. Dependence of the activity of the obtained glutamate dehydrogenase on the $\mathrm{pH}$ value for the reductive amination

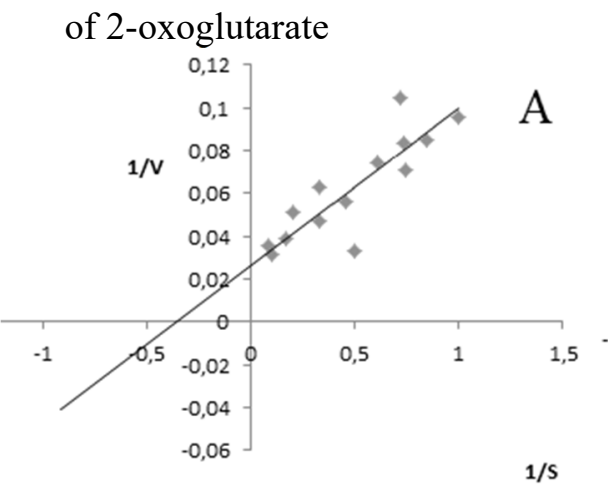

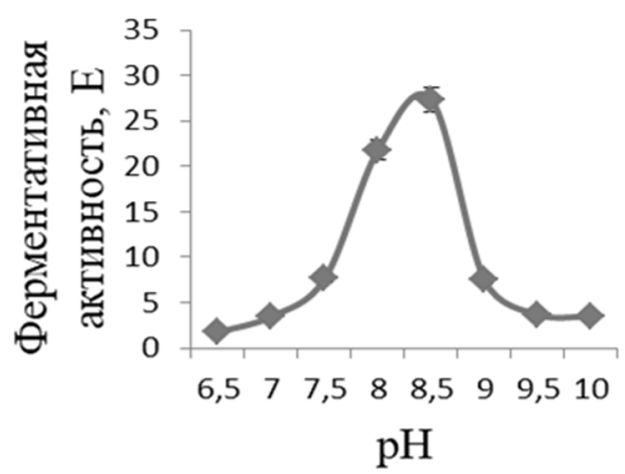

Рис. 3. Зависимость активности полученного препарата глутаматдегидрогеназы от значения $\mathrm{pH}$ для реакции дезаминирования глутамата

Fig. 3. Dependence of the activity of the obtained glutamate dehydrogenase on the $\mathrm{pH}$ for the deamination of glutamate

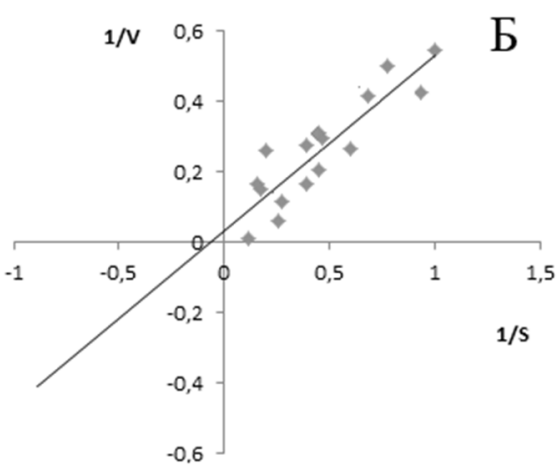

Рис. 4. Определение константы Михаэлиса полученного ферментного препарата: А - по 2-оксоглутарату; Б - по глутамату.

Fig. 4. Determination of the Michaelis constant of the obtained enzyme:

$$
\text { A - for 2-oxoglutarate; B - for glutamate }
$$

Таблица 2. Значения констант Михаэлиса и оптимальных значений $\mathrm{pH}$ для препарата глутаматдегидрогеназы $(\mathrm{n}=3, \mathrm{p} \leq 0.05)$

Table 2. Michaelis constants and optimal $\mathrm{pH}$ values for the glutamate dehydrogenase preparation $(\mathrm{n}=3, \mathrm{p} \leq 0.05)$

\begin{tabular}{|c|c|c|c|c|}
\hline & $\begin{array}{c}\text { Км по 2-Ог, } \\
\text { мМ }\end{array}$ & $\begin{array}{c}\text { Км по Глут, } \\
\text { мМ }\end{array}$ & $\begin{array}{c}\mathrm{pH} \text { - оптимум по реак- } \\
\text { ции аминирования }\end{array}$ & $\begin{array}{c}\mathrm{pH} \text { - оптимум по реакции } \\
\text { дезаминирования }\end{array}$ \\
\hline ГДГ & 2.75 & 14.9 & 8.5 & 8.5 \\
\hline
\end{tabular}

\section{Заключение}

Таким образом, разработана пятистадийная схема очистки ГДГ из проростков пшеницы. Полученная ГДГ очищена в 319.5 раз с удельной активностью 377 Е/мг белка и выходом 3.7\%. Проведение ПААГ-электрофореза с последующим окрашиванием нитратом серебра позволило продемонстрировать гомогенность очищенного ферментного препарата глутаматдегидрогеназы. Исследованы некоторые свойства очищенной глутаматдегидрогеназы. Величина рН-оптимума и для реакции восстановительного аминирования, и для реакции дезаминирования равняется 8.5. Установлены значения констант Михаэлиса по 2-оксоглутарату и по глутамату, которые составляют 2.75 и 14.9 мМ, соответственно. 
Работа выполнена при поддержке Министерства науки и высшего образования РФ в рамках государственного задания ВУЗам в сфере научной деятельности на 20202022 годы, проект № FZGU-2020-0044.

\section{Список литературы}

1. Eduardo S., Ana B. Hervás, Canosa I. et al. // InTech. 2012. pp. 289-318. DOI: $10.5772 / 47767$

2. Pasquo A., Britton K.L., Stillman T.J., Rice D.W. et al. // Biochim. Biophys. Acta. 1996. Vol. 1297. pp. 149-158. DOI: $10.1016 /$ s0167-4838(96)00017-9

3. Garnier A., Berredjem A., Botton B. // Fungal Genetics and Biology. 1997. Vol. 22. pp. 168-176. DOI: 10.1006/fgbi.1997.1004

4. Hammer B.A., Johnson E.A. // Arch. Microbiol. 1988. Vol. 150. pp. 460-464. DOI: 10.1007/BF00422287

5. Lam H.M., Coschigano K.T., Oliveira I.C., Melo-Oliveira R. et al. // Annu Rev Plant Physiol Plant Mol Biol. 1996. Vol. 47. pp. 569593. DOI: 10.1146/annurev.arplant.47.1.569

6. Nagel M., Hartmann T. // Naturforsch. 1980. Vol. 35. pp. 406-415. DOI: 10.1515/znc1980-5-610

7. Turano F.J., Thakkar S.S., Fang T., Weisemann J.M. // Plant Physiol. 1997. Vol. 113. No 4. pp. 1329-41. DOI: 10.1104/ pp.113.4.1329

8. Turano F., Dashner R., Upadhyaya A., Caldwell C.R. // Plant physiology. 1996. Vol. 112. pp. 1357-1 364. DOI: 10.1104/ pp.112.3.1357

9. Consalvi V., Chiaraluce R., Politi L., Scandurra R. // Comp. Biochem. Physiol. B. 1994. Vol. 109. pp. 691-699. DOI: 10.1016/ 0305-0491(94)90132-5

10. Kujo C., Oshima T. // Appl. Environ. Microbiol. 1998. Vol. 64. pp. 2152-2157. DOI: 10. 1128/AEM.64.6.2152-2157.1998

11. Селеменев В.Ф., Рудаков О.Б., Славинская Г.В., Дроздова Н.В. Пигменты пищевых производств (меланоидины). М. ДеЛи принт. 2008. $246 \mathrm{c}$.
12. Ramirez H., Maria J. Delgado, GarciaPeregrin E. // Pflanzenphysiol., 1977, Vol. 84, pp. 109-119. DOI: $10.1016 / \mathrm{S} 0044-328 \mathrm{X}(77)$ 80183-9

13. Grabowska A., Zdunek-Zastocka E., Kutryn E., Kwinta J. // Acta Physiol Plant. 2017. Vol. 39. No 24. DOI 10.1007/s11738-016-23224 страницы

14. Purnell M.P., Botella J.R. // Plant Physiol. 2007. Vol. 143. No 1. pp. 530-539. DOI 10.1007/s00425-005-1510-z

15. Sarasketa A, Gonzalez-Moro M.B, Gonzalez-Murua C, Marino D // Front. Plant Sci. 2016, Vol. 7. pp. 1-12. DOI:10.3389/ fpls.2016.00029

16. Yamaya T., Oaks A., Matumoto H. // Plant Physiology. 1984. Vol. 76. pp. 1009-1013. DOI: $10.1104 /$ pp.76.4.1009

17. Eprintsev A.T., Fedorin D.N., Nikitina M.V. Igamberdiev A.U. // Journal of Plant Physiology. 2015. Vol. 181. pp. 14-19. DOI: 10.1016/j.jplph.2015.03.012

18. Рудаков О.Б., Селеменев В.Ф. Физико-химические системы. Сорбат-сорбентэлюент в жидкостной хроматографии. Воронеж. 2003. 240 c.

19. Davis B.J.// Ann. N. Y. Acad. Sci. 1994. Vol. 121. pp. 404-427.

20. Shevchenko A., Wilm M., Vorm O., Mann M. // Anal. Chem. 1996. Vol. 68, pp. 850858. DOI: $10.1021 /$ ac950914h

21. Magalhaes J.R., Ju G.C., Rich P.J., Rhodes D. // Plant Physiol. 1990. Vol. 94. pp. 647-656.

22. Lowry O.H., Rosebrough N.J., Farr A.L., Randall R.J. // J. Biol. Chem. 1951. Vol. 193. pp. $265-275$.

23. Лакин Г.Ф. Биометрия. М. Высш. шк. 1990. $351 \mathrm{c}$.

24. Епринцев А.Т., Анохина Г.Б., Оя П.С., Дедов Я.И. // Прикладная биохимия и микробиология. 2021. Т. 57. № 2. С. 163-171. 


\title{
The use of ion exchange chromatography for the production of homogeneous glutamate dehydrogenase from wheat seedlings
}

\author{
(C) 2021 Anokhina G.B., Dedov Ya.I., Eprintsev A.T. \\ Voronezh State University, Voronezh
}

\begin{abstract}
Homogeneous glutamate dehydrogenase (GDH, L-glutamate: NAD (P) H-oxidoreductase 1.4.1.3), purified 319.5 times with a specific activity of $377 \mathrm{U} / \mathrm{mg}$ protein and a yield of $3.7 \%$ was obtained using 5stages purification. Usually, the purification of enzymes in our laboratory is carried out according to the following general scheme: homogenization of plant material (obtaining an enzyme extract), fractionation of enzyme proteins with ammonium sulphate, gel filtration on Sephadex G-25, providing desalination of proteins, ion exchange chromatography on DEAE-Sephacel, desorption of enzymatic activity was carried out with a $\mathrm{NaCl}$ concentration gradient $(0.15-0.3 \mathrm{M})$. The last stage of purification was carried out using gel chromatography on a Sephadex G-200. It is known that ATP and metabolic intermediates (glutamate and 2-oxoglutarate) have an inhibitory effect on glutamate dehydrogenase. The activation of enzymatic activity was observed under the action of AMP, calcium and magnesium ions, and ammonium sulphate. The use of DEAE-Sephacel had the major effect out of all chromatographic methods (ion exchange chromatography, partition chromatography, gel filtration, etc.). In this case, the degree of GDH purification was more than 300 times.

The performed PAGE-electrophoresis, followed by specific staining using tetrazolium method, revealed glutamate dehydrogenase activity in the purified protein. The $\mathrm{pH}$ optimum of the obtained GDH for the reductive amination and oxidative deamination reaction was 8.5. Kinetic characteristics of the affinity of glutamate dehydrogenase to various substrates were obtained. The Michaelis constant for 2-oxoglutarate was 2.75, and for glutamate it was 14.9, which may indicate the predominance of $\beta$-subunits in the structure of the GDH oligomer. Analysis of these data indicates a significantly higher affinity of the studied enzyme for 2-oxoglutarate.
\end{abstract} aestivum.

Keywords: glutamate dehydrogenase, wheat, purification, Michaelis constant, $\mathrm{pH}$ optimum, Triticum

\section{References}

1. Eduardo S., Hervás A.B., Canosa I., Govantes F., InTech, 2012, pp. 289-318. DOI: $10.5772 / 47767$

2. Pasquo A., Britton K.L., Stillman T.J., Rice D.W. et al., Biochim. Biophys. Acta, 1996, Vol. 1297 , pp. 149-158. DOI: $10.1016 / \mathrm{s} 0167-$ 4838(96)00017-9

3. Garnier A., Berredjem A., Botton B., Fungal Genetics and Biology, 1997, Vol. 22, pp. 168-176. DOI: 10.1006/fgbi.1997.1004

4. Hammer B.A., Johnson E.A., Arch. Microbiol, 1988, Vol. 150, pp. 460-464. DOI: 10.1007/BF00422287

5. Lam H.M., Coschigano K.T., Oliveira I.C., Melo-Oliveira R. et al., Annu Rev Plant Physiol Plant Mol Biol, 1996, Vol. 47, pp. 569-593. DOI: 10.1146/annurev.arplant.47.1.569

6. Nagel M., Hartmann T., Naturforsch, 1980, Vol. 35, pp. 406-415. DOI: 10.1515/znc-1980-5610

7. Turano F.J., Thakkar S.S., Fang T., Weisemann J.M., Plant Physiol, 1997, Vol. 113, No 4, pp. 1329-41. DOI: 10.1104/pp.113.4.1329
8. Turano F., Dashner R., Upadhyaya A., Caldwell C.R., Plant physiology, 1996, Vol. 112, pp. 1357-1 364. DOI: 10.1104/pp.112.3. 1357

9. Consalvi V., Chiaraluce R., Politi L., Scandurra R., Comp. Biochem. Physiol. B, 1994, Vol. 109, pp. 691-699. DOI: 10.1016/ 0305-0491(94)90132-5

10.Kujo C., Oshima T., Appl. Environ. Microbiol, 1998, Vol. 64, pp. 2152-2157. DOI: 10. 1128/AEM.64.6.2152-2157.1998

11.Selemenev V.F., Rudakov O.B., Slavinskaya G.V., Drozdova N.V. Pigments for food production (melanoidins), M., DeLi print, 2008, $246 \mathrm{p}$.

12.Ramirez H., Maria J. Delgado, Garcia-Peregrin E., Pflanzenphysiol, 1977, Vol. 84, pp. 109-119. DOI: 10.1016/S0044-328X(77)80183-9

13.Grabovska A., Zdunek-Zastocka E., Kutryn E., Kwinta J., Acta Physiol Plant, 2017, Vol. 39, No 24, DOI 10.1007/s11738-016-2322-4

14.Purnell M.P., Botella J.R., Plant Physiol, 2007, Vol. 143, No 1, pp. 530-539. DOI $10.1007 / \mathrm{s} 00425-005-1510-\mathrm{z}$ 
15.Sarasketa A, Gonzalez-Moro M.B, Gonzalez-Murua C, Marino D., Front. Plant Sci, 2016, Vol. 7, pp. 1-12. DOI:10.3389/fpls.2016.00029

16. Yamaya T., Oaks A., Matumoto H., Plant Physiology, 1984, Vol. 76, pp. 1009-1013. DOI: 10.1104/pp.76.4.1009

17.Eprintsev A.T., Fedorin D.N., Nikitina M.V. Igamberdiev A.U., Journal of Plant Physiology, 2015, Vol. 181, pp. 14-19. DOI: 10.1016/j.jplph.2015.03.012

18.Rudakov O.B., Selemenev V.F., Fizikohimicheskie sistemy. Sorbat-sorbene-jeljujent v zhidkostnoj hromatografii, Voronezh, 2003, 240 p.

19.Davis B.J., Ann. N. Y. Acad. Sci, 1994, Vol. 121, pp. 404-427.

\footnotetext{
Анохина Галина Борисовна - аспирант кафедры биохимии и физиологии клетки, м.н.с., Воронежский государственный университет, Воронеж

Епринцев Александр Трофимович - профессор кафедры биохимии и физиологии клетки, заведующий кафедрой биохимии и физиологии клетки, д.б.н., Воронежский государственный университет, Воронеж

Дедов Ярослав Игоревич - магистр кафедры биохимии и физиологии клетки, Воронежский государственный университет, Воронеж
}

20.Shevchenko A., Wilm M., Vorm O., Mann M., Anal. Chem, 1996, Vol. 68, pp. 850-858. DOI: $10.1021 / \mathrm{ac} 950914 \mathrm{~h}$

21.Magalhaes J.R., Ju G.C., Rich P.J., Rhodes D., Plant Physiol, 1990, Vol. 94, pp. 647-656.

22.Lowry O.H., Rosebrough N.J., Farr A.L., Randall R.J., J. Biol. Chem, 1951, Vol. 193, pp. 265-275.

23.Lakin G.F. Biometrija. M., Vysh. shk., 1990, $351 \mathrm{p}$.

24.Eprintsev A.T., Anokhina G.B., Oya P.S., Dedov Y.I., Prikladnaja biohimija i mikrobiologija, 2021, Vol. 57, No 2, pp. 163-171.

Anokhina Galina B. - Postgraduate student, Department of Biochemistry and Cell Physiology, Voronezh State University, Voronezh, e-mail: Dowi2009@mail.ru

Eprintsev Alexandr T. - Doctor of Biological Sciences, Professor, Head of the Department of Biochemistry and Cell Physiology, Voronezh State University, Voronezh, e-mail: bc366@bio.vsu.ru

Dedov Yaroslav I. - Student, Department of Biochemistry and Cell Physiology, Voronezh State University, Voronezh, e-mail: bc366@bio.vsu.ru 